\title{
High Entropy Oxide Phases with Perovskite Structure
}

\author{
Denis A. Vinnik ${ }^{1, *}$, Evgeny A. Trofimov ${ }^{1}$, Vladimir E. Zhivulin ${ }^{1}$, Svetlana A. Gudkova ${ }^{1,2}$, \\ Olga V. Zaitseva ${ }^{1}$, Dmitry A. Zherebtsov ${ }^{1} \mathbb{D}^{\mathbb{D}}$, Andrey Yu. Starikov ${ }^{1} \mathbb{D}$, Darya P. Sherstyuk ${ }^{1}$, \\ Abdulkarim A. Amirov ${ }^{3,4}$, Alexandr V. Kalgin ${ }^{5,6}$, Sergey V. Trukhanov ${ }^{1,7,8}$ and \\ Fedor V. Podgornov ${ }^{1}$ \\ 1 Material science and physics\&chemistry of materials, South Ural State University (National Research \\ University), 454080 Chelyabinsk, Russia; trofimovea@susu.ru (E.A.T.); zhivulinve@susu.ru (V.E.Z.); \\ gudkovasa@susu.ru (S.A.G.); nikonovaov@susu.ru (O.V.Z.); zherebtsovda@susu.ru (D.A.Z.); \\ starikovau@susu.ru (A.Y.S.); sherstyukdp@susu.ru (D.P.S.); truhanovsv@susu.ru or \\ sv_truhanov@mail.ru (S.V.T.) podgornovfv@susu.ru (F.V.P.) \\ 2 Moscow Institute of Physics and Technology (State University), 141701 Dolgoprudny, Russia \\ 3 Immanuel Kant Baltic Federal University, 236041 Kaliningrad, Russia; amiroff_a@mail.ru \\ 4 Amirkhanov Institute of Physics Daghestan Scientific Center, Russian Academy of Sciences, \\ 360015 Makhachkala, Russia \\ 5 Voronezh State Technical University, 394000 Voronezh, Russia; kalgin_alexandr@mail.ru \\ 6 Voronezh State University, 394036 Voronezh, Russia \\ 7 National University of Science and Technology “MISIS", 119049 Moscow, Russia \\ 8 Scientific and Practical Materials Research Centre of NAS of Belarus, 220072 Minsk, Belarus \\ * Correspondence: vinnikda@susu.ru; Tel.: +7-951-457-2286
}

Received: 11 January 2020; Accepted: 3 February 2020; Published: 5 February 2020

\begin{abstract}
The possibility of the formation of high entropy single-phase perovskites using solid-state sintering was investigated. The $\mathrm{BaO}-\mathrm{SrO}-\mathrm{CaO}-\mathrm{MgO}-\mathrm{PbO}-\mathrm{TiO}_{2}, \mathrm{BaO}-\mathrm{SrO}-\mathrm{CaO}-\mathrm{MgO}-\mathrm{PbO}-\mathrm{Fe}_{2} \mathrm{O}_{3}$ and $\mathrm{Na}_{2} \mathrm{O}-\mathrm{K}_{2} \mathrm{O}-\mathrm{CaO}-\mathrm{La}_{2} \mathrm{O}_{3}-\mathrm{Ce}_{2} \mathrm{O}_{3}-\mathrm{TiO}_{2}$ oxide systems were investigated. The optimal synthesis temperature is found between 1150 and $1400{ }^{\circ} \mathrm{C}$, at which the microcrystalline single phase with perovskite structure was produced. The morphology, chemical composition, crystal parameters and dielectric properties were studied and compared with that of pure $\mathrm{BaTiO}_{3}$. According to the EDX data, the single-phase product has a formula of $\mathrm{Na}_{0.30} \mathrm{~K}_{0.07} \mathrm{Ca}_{0.24} \mathrm{La}_{0.18} \mathrm{Ce}_{0.21} \mathrm{TiO}_{3}$ and a cubic structure.
\end{abstract}

Keywords: phase equilibria; multicomponent oxides; high entropy phases; perovskite; solid-phase sintering

\section{Introduction}

The synthesis of high entropy ceramic materials, primarily oxide phases and the study of their properties, is a direction that has been actively developed in recent years. To date, the literature presents the results of properties studies of various oxide high entropy systems [1-15] as well as attempts of generalizing the experience of producing such phases [2-6].

Early work in this direction began with the study of rock salt type oxide systems formed only by divalent metals like $\mathrm{Mg}, \mathrm{Co}, \mathrm{Ni}, \mathrm{Cu}, \mathrm{Zn}[8,11,12]$ or only rare earth elements (Ce, Gd, La, Nd, Pr, Sm, $\mathrm{Y})[13,14]$. In [15], a high-entropy fluorite type structure was obtained in a system formed by $\mathrm{CeO}_{2}$, $\mathrm{ZrO}_{2}, \mathrm{HfO}_{2}, \mathrm{TiO}_{2}$ and $\mathrm{SnO}_{2}$. Later was appeared works devoted to the high entropy oxide systems with a more complex structure. In [16] formation of a multicomponent oxide phase with a spinel structure was reported. Our group initiated studies on high entropy phases with magnetoplumbite structure [17-19].

The authors of [20-24] presented high entropy phases with a perovskite structure. In [20], homogeneous high entropy perovskites were obtained in the systems: $\operatorname{Sr}\left(\mathrm{Zr}_{0.2} \mathrm{Sn}_{0.2} \mathrm{Ti}_{0.2} \mathrm{Hf}_{0.2} \mathrm{Mn}_{0.2}\right) \mathrm{O}_{3}$, $\operatorname{Sr}\left(\mathrm{Zr}_{0.2} \mathrm{Sn}_{0.2} \mathrm{Ti}_{0.2} \mathrm{Hf}_{0.2} \mathrm{Nb}_{0.2}\right) \mathrm{O}_{3}, \quad \mathrm{Ba}\left(\mathrm{Zr}_{0.2} \mathrm{Sn}_{0.2} \mathrm{Ti}_{0.2} \mathrm{Hf}_{0.2} \mathrm{Ce}_{0.2}\right) \mathrm{O}_{3}, \quad \mathrm{Ba}\left(\mathrm{Zr}_{0.2} \mathrm{Sn}_{0.2} \mathrm{Ti}_{0.2} \mathrm{Hf}_{0.2} \mathrm{Y}_{0.2}\right) \mathrm{O}_{(3-x)}$, 
$\mathrm{Ba}\left(\mathrm{Zr}_{0.2} \mathrm{Sn}_{0.2} \mathrm{Ti}_{0.2} \mathrm{Hf}_{0.2} \mathrm{Nb}_{0.2}\right) \mathrm{O}_{3}$ and $\left(\mathrm{Sr}_{0.5} \mathrm{Ba}_{0.5}\right)\left(\mathrm{Zr}_{0.2} \mathrm{Sn}_{0.2} \mathrm{Ti}_{0.2} \mathrm{Hf}_{0.2} \mathrm{Nb}_{0.2}\right) \mathrm{O}_{3}$. Analyzing the results, the authors, first of all, compare how much the Goldschmidt rule (connecting the isomorphism with the difference in the ionic radii) allows us to predict the possibility of the system stabilization. The authors of [21] studied the effect of high entropy on the stabilization of a $\left(\mathrm{Gd}_{0.2} \mathrm{La}_{0.2} \mathrm{Nd}_{0.2} \mathrm{Sm}_{0.2} \mathrm{Y}_{0.2}\right)\left(\mathrm{Co}_{0.2} \mathrm{Cr}_{0.2} \mathrm{Fe}_{0.2} \mathrm{Mn}_{0.2} \mathrm{Ni}_{0.2}\right) \mathrm{O}_{3}$ system. The experiments made it possible to explain the reliance on the configurational entropy of mixing of the system. The authors of [22] obtained $\operatorname{Sr}\left(\left(\mathrm{Zr}_{0.94} \mathrm{Y}_{0.06}\right)_{0.2} \mathrm{Sn}_{0.2} \mathrm{Ti}_{0.2} \mathrm{Hf}_{0.2} \mathrm{Mn}_{0.2}\right) \mathrm{O}_{3-x}$ perovskite phase using reactive spark plasma sintering. In [23], the high entropy perovskite film $\mathrm{Ba}\left(\mathrm{Zr}_{0.2} \mathrm{Sn}_{0.2} \mathrm{Ti}_{0.2} \mathrm{Hf}_{0.2} \mathrm{Nb}_{0.2}\right) \mathrm{O}_{3}$ was obtained by pulsed laser deposition on $\mathrm{SrTiO}_{3}$ and $\mathrm{MgO}$ substrates. Finally, in [24], the general problems of the thermodynamic description and modeling of high entropy ceramics were considered. A number of approaches were illustrated using the $\mathrm{LaMnO}_{3 \pm \delta}$ perovskite as an example.

The present work is aimed at studying the possibility of obtaining high entropy perovskite phases in the $\mathrm{BaO}-\mathrm{SrO}-\mathrm{CaO}-\mathrm{MgO}-\mathrm{PbO}-\mathrm{TiO}_{2}, \mathrm{BaO}-\mathrm{SrO}-\mathrm{CaO}-\mathrm{MgO}-\mathrm{PbO}-\mathrm{Fe}_{2} \mathrm{O}_{3}$ and $\mathrm{Na}_{2} \mathrm{O}-\mathrm{K}_{2} \mathrm{O}-\mathrm{CaO}-\mathrm{La}_{2} \mathrm{O}_{3}-\mathrm{Ce}_{2} \mathrm{O}_{3}-\mathrm{TiO}_{2}$ systems. It was assumed that the results of the study will allow us to point out the contribution of heterovalent isomorphism (within A sublattice of perovskite $\mathrm{ABO}_{3}$ ) to the stabilization of high entropy perovskites.

\section{Materials and Methods}

The $99.0 \%-99.5 \%$ pure oxides and carbonates were used as the initial components for the synthesis: $\mathrm{BaCO}_{3}, \mathrm{SrCO}_{3}, \mathrm{CaO}, \mathrm{MgO}, \mathrm{PbO}, \mathrm{Na}_{2} \mathrm{CO}_{3}, \mathrm{~K}_{2} \mathrm{CO}_{3}, \mathrm{La}_{2} \mathrm{O}_{3}, \mathrm{Ce}_{2} \mathrm{O}_{3}, \mathrm{Fe}_{2} \mathrm{O}_{3}, \mathrm{TiO}_{2}$. The three batch compositions (Table 1 ) were targeted formulas:

1. $\left(\mathrm{Ba}_{0.2} \mathrm{Sr}_{0.2} \mathrm{Ca}_{0.2} \mathrm{Mg}_{0.2} \mathrm{~Pb}_{0.2}\right) \mathrm{TiO}_{3}$;

2. $\left(\mathrm{Ba}_{0.2} \mathrm{Sr}_{0.2} \mathrm{Ca}_{0.2} \mathrm{Mg}_{0.2} \mathrm{~Pb}_{0.2}\right) \mathrm{FeO}_{3}$;

3. $\left(\mathrm{Na}_{0.2} \mathrm{~K}_{0.2} \mathrm{Ca}_{0.2} \mathrm{La}_{0.2} \mathrm{Ce}_{0.2}\right) \mathrm{TiO}_{3}$.

Table 1. The batch compositions for synthesis, wt. $\%$.

\begin{tabular}{cccccccccccc}
\hline № & $\mathrm{TiO}_{2}$ & $\mathrm{Fe}_{2} \mathrm{O}_{3}$ & $\mathrm{BaCO}_{3}$ & $\mathrm{SrCO}_{3}$ & $\mathrm{CaO}$ & $\mathrm{MgO}$ & $\mathrm{PbO}$ & $\mathrm{Na}_{2} \mathrm{CO}_{3}$ & $\mathbf{K}_{2} \mathrm{CO}_{3}$ & $\mathrm{La}_{2} \mathrm{O}_{3}$ & $\mathrm{Ce}_{2} \mathrm{O}_{3}$ \\
\hline 1 & 37.535 & - & 18.549 & 13.877 & 5.271 & 3.788 & 20.98 & - & - & - & - \\
2 & - & 37.529 & 18.551 & 13.878 & 5.272 & 3.789 & 20.982 & - & - & - & - \\
3 & 44.148 & - & - & - & 6.2 & - & - & 5.859 & 7.64 & 18.01 & 18.144 \\
\hline
\end{tabular}

The thoroughly mixed and ground powders were pressed into pellets. The laboratory resistance furnace with an air atmosphere was used for sintering. The samples were kept in the furnace with the predetermined temperatures for $5 \mathrm{~h}$.

The sintering temperatures optimization was the goal of preliminary experiments. During that stage, the samples were sintered at temperatures from 1000 to $1400{ }^{\circ} \mathrm{C}$ with an interval of $50{ }^{\circ} \mathrm{C}$. Then the samples were investigated using the scanning electron microscope Jeol JSM7001F (Jeol, Tokyo, Japan). The criterion for optimal temperature was the size and morphology of the formed crystals. It was necessary to select a temperature that, on the one hand, would ensure the well-shaped perovskite crystals formation and on the other hand this temperature should not lead to the crystal melting.

According to the preliminary experiments the optimal temperature for the first and third composition is $1400^{\circ} \mathrm{C}$, and the second composition it is $1150{ }^{\circ} \mathrm{C}$. Above these temperatures, samples start melting. Since the first and second sample has the only difference in Ti to Fe substitution, it is matter of iron to depress the melting point of a material. At the end of the heat treatment, the samples were cooled, after which the pellets were examined. The Oxford INCA X-max 80 X-ray spectrometer (Oxford, High Wycomb, USA) was used for elemental analysis. The structure was investigated using a Rigaku Ultima IV powder X-ray diffractometer (Jeol, Tokyo, Japan). 
For dielectric measurements, the samples were polished to form of thin disks with smooth and parallel surfaces and thicknesses about $0.5 \mathrm{~mm}$. The electric contacts were made from silver adhesive and covered on the top and bottom surfaces of samples and then annealed at $120{ }^{\circ} \mathrm{C}$ for $30 \mathrm{~min}$.

The low-field dielectric measurements (real part of permittivity and the loss angle tangent $(\tan \delta)$ ) were carried out at fixed frequencies from $25 \mathrm{~Hz}$ to $1 \mathrm{MHz}$ over the temperature range from $20^{\circ} \mathrm{C}$ to $600^{\circ} \mathrm{C}$ using an immittance meter meter (E7-20 type) (OJSC «MNIPI», Minsk, Belarus). The measurements were conducted in air with rate of $2^{\circ} \mathrm{C} / \mathrm{min}$ in the heating protocol.

The permittivity as function of temperature were calculated using Equation (1):

$$
\varepsilon(T)=\frac{4 d C(T)}{\varepsilon_{0} \pi D^{2}},
$$

from well-known equation for thin capacitor

$$
C=\frac{\varepsilon \varepsilon_{0} S}{d}
$$

where the $S$-area of capacitor's disc plate with diameter $D\left(S=\frac{\pi * D^{2}}{4}\right), d$-thickness of capacitor, $\varepsilon_{0}$-electric constant $\left(8.85 \times 10^{-12} \mathrm{~F} / \mathrm{m}\right)$.

The scheme of dielectric measurements shown in Figure 1. The sample (1) in the form of a thin-disc capacitor with silver paste contacts (2) was clamped between special electrodes (3) and connected to LCR-meter. The sample was placed into thermo-insulated adiabatic chamber (4). The temperature of the sample was controlled by K type thermocouple (5) and adjusted by the heater (6). The accuracy of temperature measurements was $0.5 \mathrm{~K}$.

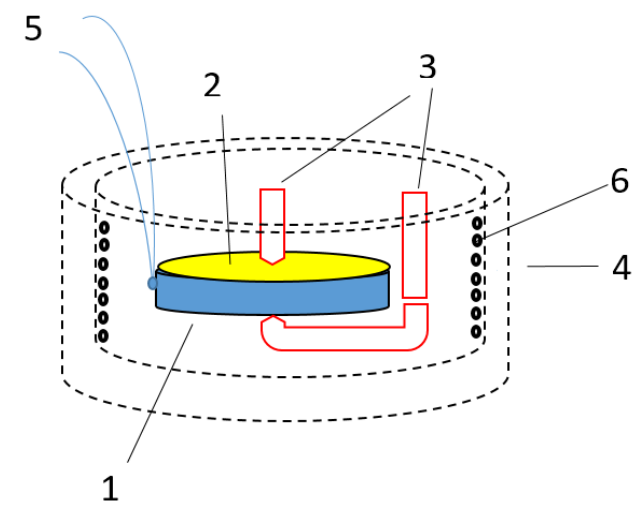

Figure 1. Scheme of dielectric measurements. 1-sample, 2-silver electric contact, 3-connected to LCR-meter electrodes, 4-thermos insulated camera, 5-thermocouple, 6-heater.

\section{Results}

This section provides a description of the experimental results of the morphology, chemical composition, crystal structure, dielectric properties investigation.

\subsection{Morphology and Chemical Composition}

The perovskite crystals were formed as cubes of $\mu \mathrm{m}$ size on a free surface of pellets (Figures 2-4). 


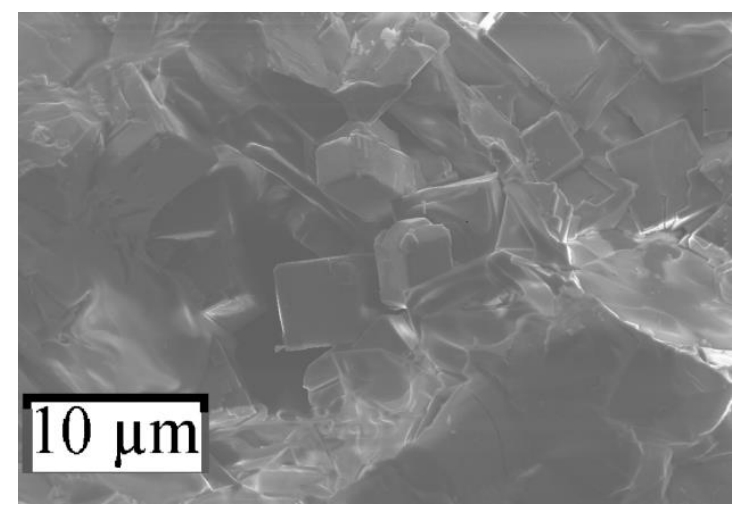

Figure 2. SEM image of sample № 1.

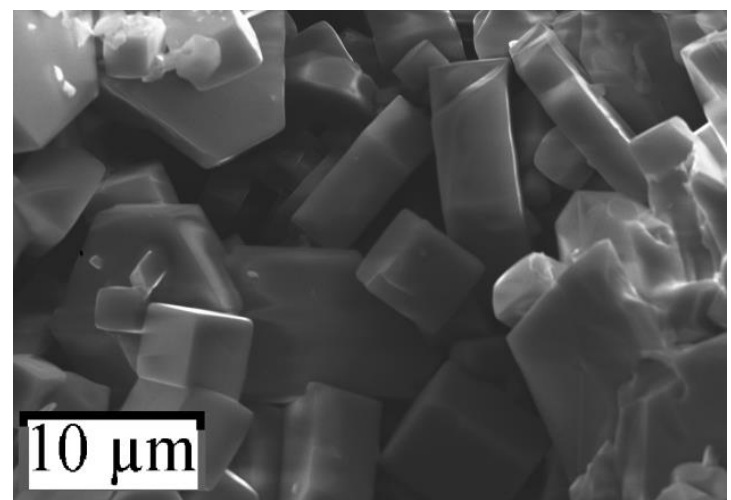

Figure 3. SEM image of sample № 2 .

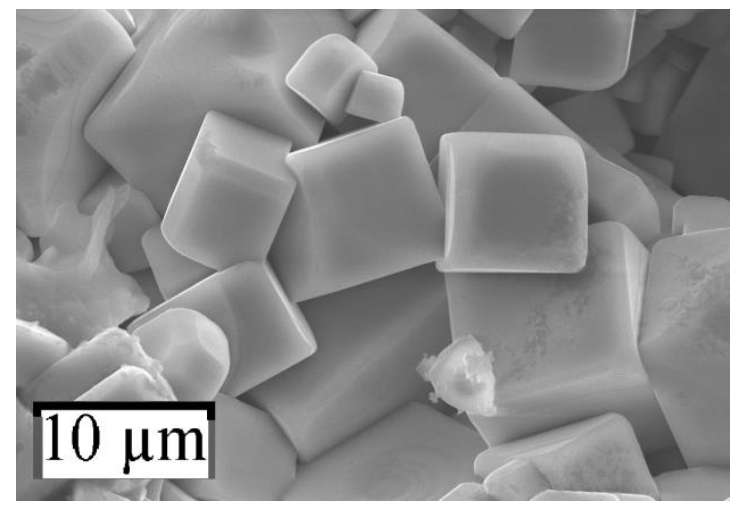

Figure 4. SEM image of sample № 3 .

\subsection{Crystal Structure}

The powder X-ray diffraction data reveals that samples 1 and 2 contained, besides perovskite, one or more extra phases that made it hard to refer to a certain structure. The composition of some of the extra phases was estimated from EDX of its crystals (Table 2). The $\mathrm{Na}_{0.30} \mathrm{~K}_{0.07} \mathrm{Ca}_{0.24} \mathrm{La}_{0.18} \mathrm{Ce}_{0.21} \mathrm{TiO}_{3}$ diffraction pattern (Figure 5) could be indexed in cubic unit cell with $a=3,8650(5) \AA$. Powder diffractogram confirms high phase purity of this material. The very weak extra reflections at $26-31{ }^{\circ} \mathrm{C}$ $2 \theta$ belong to $0.5-1.5$ mass \% of unreacted oxides: $\mathrm{La}_{2} \mathrm{O}_{3}, \mathrm{CeO}_{2}$ and $\mathrm{TiO}_{2}$. The presence of minute amounts of these oxides does not much affect the specific dielectric properties of the main material. 
Table 2. The phase composition of samples.

\begin{tabular}{clcc}
\hline № & \multicolumn{4}{c}{ The Indexed Phases } \\
\hline 1 & $\mathrm{Ba}_{0.14} \mathrm{Sr}_{0.60} \mathrm{Ca}_{0.48} \mathrm{Mg}_{0.09} \mathrm{~Pb}_{0.01} \mathrm{TiO}_{3}$ & $\mathrm{Ba}_{4} \mathrm{Ti}_{11} \mathrm{O}_{26}$ & $\mathrm{Ba}_{1.2} \mathrm{Ti}_{6.8} \mathrm{Mg}_{1.2} \mathrm{O}_{16}$ \\
2 & $\mathrm{Ba}_{0.16} \mathrm{Sr}_{0.43} \mathrm{Ca}_{0.37} \mathrm{Mg}_{0.03} \mathrm{~Pb}_{0.08} \mathrm{FeO}_{3}$ & $\mathrm{BaSrFe}_{4} \mathrm{O}_{8}$ & - \\
3 & $\mathrm{Na}_{0.30} \mathrm{~K}_{0.07} \mathrm{Ca}_{0.24} \mathrm{La}_{0.18} \mathrm{Ce}_{0.21} \mathrm{TiO}_{3}$ & - & - \\
\hline
\end{tabular}

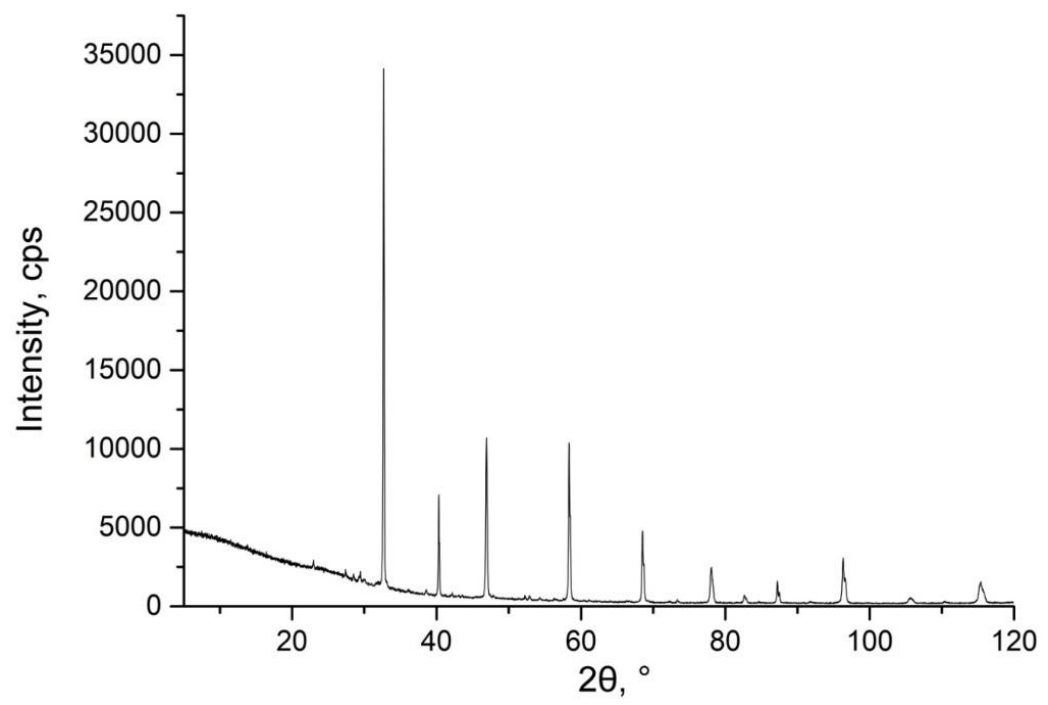

Figure 5. Experimental powder $\mathrm{X}$-ray diffraction pattern of $\mathrm{Na}_{0.30} \mathrm{~K}_{0.07} \mathrm{Ca}_{0.24} \mathrm{La}_{0.18} \mathrm{Ce}_{0.21} \mathrm{TiO}_{3}$ sample.

\subsection{Dielectric Properies}

The real part of dielectric permittivity and loss angle tangent of $\mathrm{Na}_{0.30} \mathrm{~K}_{0.07} \mathrm{Ca}_{0.24} \mathrm{La}_{0.18} \mathrm{Ce}_{0.21} \mathrm{TiO}_{3}$ as well as of pure $\mathrm{BaTiO}_{3}$ are demonstrated in Figures 6 and 7 respectively. As one can see, the loss angle tangent of $\mathrm{BaTiO}_{3}$ has significantly lower values comparing to $\mathrm{Na}_{0.30} \mathrm{~K}_{0.07} \mathrm{Ca}_{0.24} \mathrm{La}_{0.18} \mathrm{Ce}_{0.21} \mathrm{TiO}_{3}$ at all frequencies within the investigated temperature range. The local maxima of $\tan \delta$ of the high entropy sample are shifted to the low-temperature range with respect to those of $\mathrm{BaTiO}_{3}$ practically at all frequencies of probing voltage. However, there is a significant difference in the thermal behavior of $\tan \delta$ of $\mathrm{Na}_{0.30} \mathrm{~K}_{0.07} \mathrm{Ca}_{0.24} \mathrm{La}_{0.18} \mathrm{Ce}_{0.21} \mathrm{TiO}_{3}$ and $\mathrm{BaTiO}_{3}$. First, it is the growth of the loss angle tangent above $300{ }^{\circ} \mathrm{C}$. At the same time, $\mathrm{BaTiO}_{3}$ has the opposite behavior, $\tan \delta \mathrm{vs}$. T curve demonstrates a single maximum at all frequencies of the probing voltage.

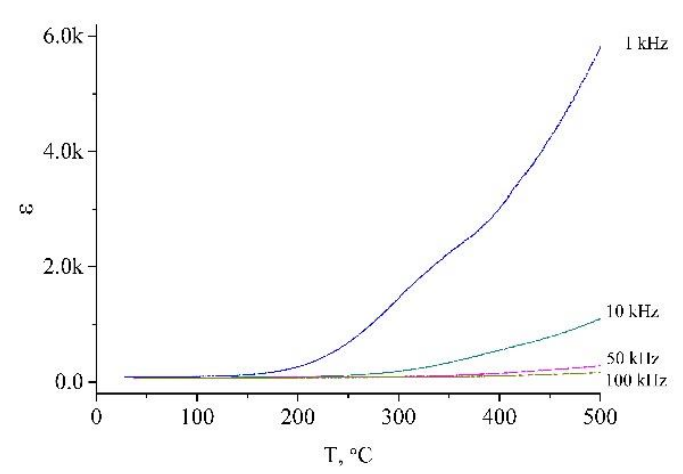

(a)

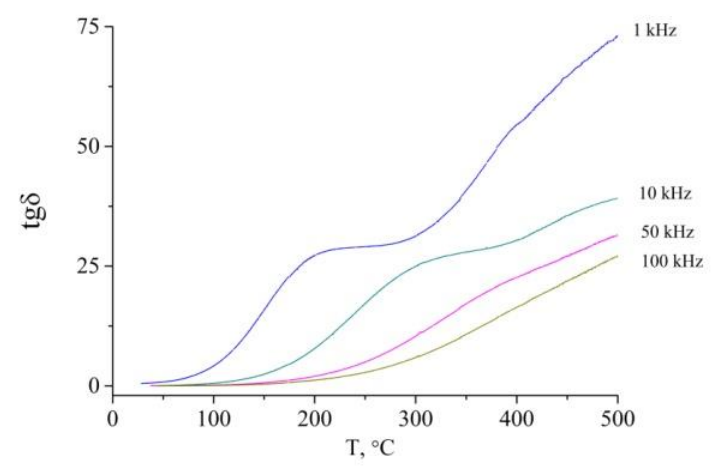

(b)

Figure 6. Dielectric parameters of $\mathrm{Na}_{0.30} \mathrm{~K}_{0.07} \mathrm{Ca}_{0.24} \mathrm{La}_{0.18} \mathrm{Ce}_{0.21} \mathrm{TiO}_{3}$ : (a) real part of dielectric permittivity, (b) loss angle tangent. 


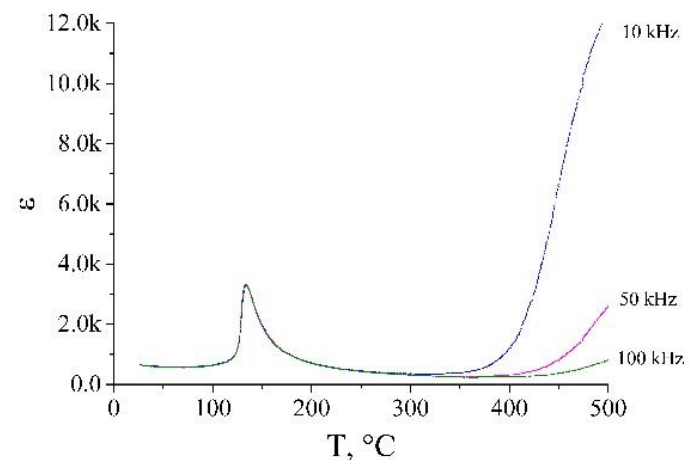

(a)

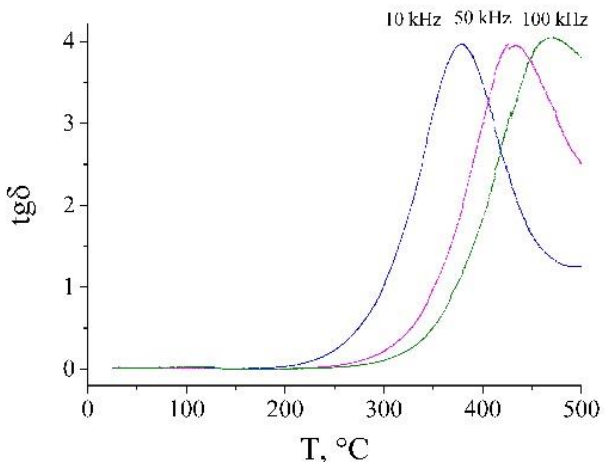

(b)

Figure 7. Dielectric parameters of $\mathrm{BaTiO}_{3}$ : (a) real part of dielectric permittivity, (b) loss angle tangent.

As follows from Figures $6 a$ and $7 \mathrm{a}$, the dependencies of the real part of the permittivity on the temperature of $\mathrm{Na}_{0.30} \mathrm{~K}_{0.07} \mathrm{Ca}_{0.24} \mathrm{La}_{0.18} \mathrm{Ce}_{0.21} \mathrm{TiO}_{3}$ and $\mathrm{BaTiO}_{3}$ demonstrate remarkably different behavior. At $\mathrm{T} \approx 120^{\circ} \mathrm{C}$, the dielectric permittivity of barium titanate has a peak at all frequencies of the probing voltage. It is explained by the phase transition of $\mathrm{BaTiO}_{3}$ from the tetragonal phase to the cubic one. It is worth to mention, that such phase transition is absent in high entropy samples. Indeed, the PXRD pattern at $20^{\circ} \mathrm{C}$ is presented only by reflections of the cubic phase. One can speculate on the broadening of temperature stability interval of cubic perovskite due to intensive doping.

With growing temperature, the dielectric permittivity grows for all frequencies for both samples. For $\mathrm{Na}_{0.30} \mathrm{~K}_{0.07} \mathrm{Ca}_{0.24} \mathrm{La}_{0.18} \mathrm{Ce}_{0.21} \mathrm{TiO}_{3}$, its growth begins at significantly lower temperatures (from $200{ }^{\circ} \mathrm{C}$ to $\left.300{ }^{\circ} \mathrm{C}\right)$ in comparison with $\mathrm{BaTiO}_{3}\left(\approx 400{ }^{\circ} \mathrm{C}\right)$. This growth is more pronounced for low frequencies, similarly to $\mathrm{BaTiO}_{3}$. This effect, as well as thermal behavior of loss angle tangent, can be explained by the relaxation of interfacial polarization (grain-grain boundary). In the case of $\mathrm{BaTiO}_{3}$, we can see only one peak in thermal dependence of the loss angle tangent. However, the high entropy sample has several different types of grains therefore it $\tan \delta$ vs $T$ curves have overlapping peaks resulting in one growing curve. This approach is also supported by the fact that the $\varepsilon(T)$ is more pronounced at low frequencies $(1-10 \mathrm{kHz})$, which are typical for the interfacial polarization.

\section{Conclusions}

A high entropy single-phase product with a perovskite structure was obtained in the present work. The calculated formula of the substituted phase was $\mathrm{Na}_{0.30} \mathrm{~K}_{0.07} \mathrm{Ca}_{0.24} \mathrm{La}_{0.18} \mathrm{Ce}_{0.21} \mathrm{TiO}_{3}$. From the PXRD data, it was concluded that the high entropy sample was the single perovskite phase. The electrodynamic investigation was performed the morphology, chemical composition, crystal structure, and dielectric properties were studied and compared with pure barium titanate $\mathrm{BaTiO}_{3}$ matrix. The polysubstituted high entropy single-phase product contains five doping elements at a high concentration level. The dielectric measurements were performed. The significant influence of high entropy composition on the microcrystals properties was observed. Due to these results, this material can be used in the electric device's design.

Author Contributions: O.V.Z., V.E.Z., A.Y.S., D.P.S. and D.A.Z. conceived and designed the experiments; S.A.G. and E.A.T. contributed powder XRD measurements; A.A.A., and A.V.K. contributed dielectric measurements; D.A.V., S.V.T. and F.V.P. wrote the paper. All authors have read and agreed to the published version of the manuscript.

Funding: The work was supported by the Russian Science Foundation, project No. 19-73-10046.

Conflicts of Interest: The authors declare no conflict of interest. 


\section{References}

1. Murty, B.S.; Yeh, J.-W.; Ranganathan, S.; Bhattacharjee, P.P. High-Entropy Alloys, 2nd ed.; Elsevier: Amsterdam, The Netherlands, 2019; p. 388.

2. Gu, J.; Zou, J.; Zhang, F.; Ji, W.; Wang, H.; Wang, W.; Fu, Z. Recent Progress in High-Entropy Ceramic Materials. Mater. China 2019, 38, 855-865. [CrossRef]

3. Sarkar, A.; Wang, Q.; Schiele, A.; Chellali, M.R.; Bhattacharya, S.S.; Wang, D.; Brezesinski, T.; Hahn, H.; Velasco, L.; Breitung, B. High-Entropy Oxides: Fundamental Aspects and Electrochemical Properties. Adv. Mater. 2019, 31, 1806236. [CrossRef]

4. Chellali, M.; Sarkar, A.; Nandam, S.; Bhattacharya, S.; Breitung, B.; Hahn, H.; Velasco Estrada, L. On the homogeneity of high entropy oxides: An investigation at the atomic scale. Scr. Mater. 2019, 166. [CrossRef]

5. Witte, R.; Sarkar, A.; Kruk, R.; Eggert, B.; Brand, R.A.; Wende, H.; Hahn, H. High-entropy oxides: An emerging prospect for magnetic rare-earth transition metal perovskites. Phys. Rev. Mater. 2019, 3, 34406. [CrossRef]

6. Rost, C.M.; Sachet, E.; Borman, T.; Moballegh, A.; Dickey, E.C.; Hou, D.; Jones, J.L.; Curtarolo, S.; Maria, J.-P. Entropy-stabilized oxides. Nat. Commun. 2015, 6, 8485. [CrossRef]

7. Bérardan, D.; Franger, S.; Dragoe, D.; Meena, A.K.; Dragoe, N. Colossal dielectric constant in high entropy oxides. Phys. Status Solidi Rapid Res. Lett. 2016, 10, 328-333. [CrossRef]

8. Sarkar, A.; Djenadic, R.; Usharani, N.J.; Sanghvi, K.P.; Chakravadhanula, V.S.K.; Gandhi, A.S.; Hahn, H.; Bhattacharya, S.S. Nanocrystalline multicomponent entropy stabilised transition metal oxides. J. Eur. Ceram. Soc. 2017, 37, 747-754. [CrossRef]

9. Bérardan, D.; Franger, S.; Meena, A.K.; Dragoe, N. Room temperature lithium superionic conductivity in high entropy oxides. J. Mater. Chem. A 2016, 4, 9536-9541. [CrossRef]

10. Rak, Z.; Rost, C.M.; Lim, M.; Sarker, P.; Toher, C.; Curtarolo, S.; Maria, J.-P.; Brenner, D.W. Charge compensation and electrostatic transferability in three entropy-stabilized oxides: Results from density functional theory calculations. J. Appl. Phys. 2016, 120, 95105. [CrossRef]

11. Rost, C.M.; Rak, Z.; Brenner, D.W.; Maria, J.P. Local structure of the $\mathrm{Mg}_{\mathrm{x}} \mathrm{Ni}_{\mathrm{x}} \mathrm{Co}_{\mathrm{x}} \mathrm{Cu}_{\mathrm{x}} \mathrm{Zn} \mathrm{x} \mathrm{O}(\mathrm{x}=0.2)$ entropy-stabilized oxide: An EXAFS study. J. Am. Ceram. Soc. 2017, 100, 2732-2738. [CrossRef]

12. Bérardan, D.; Meena, A.; Franger, S.; Herrero, C.; Dragoe, N. Controlled Jahn-Teller distortion in (MgCoNiCuZn)O-based high entropy oxides. J. Alloys Compd. 2017, 704. [CrossRef]

13. Sarkar, A.; Loho, C.; Velasco, L.; Thomas, T.; Bhattacharya, S.S.; Hahn, H.; Djenadic, R. Multicomponent equiatomic rare earth oxides with a narrow band gap and associated praseodymium multivalency. Dalton Trans. 2017, 46, 12167-12176. [CrossRef]

14. Djenadic, R.; Sarkar, A.; Clemens, O.; Loho, C.; Botros, M.; Chakravadhanula, V.S.K.; Kübel, C.; Bhattacharya, S.S.; Gandhi, A.S.; Hahn, H. Multicomponent equiatomic rare earth oxides. Mater. Res. Lett. 2017, 5, 102-109. [CrossRef]

15. Chen, K.; Pei, X.; Tang, L.; Cheng, H.; Li, Z.; Li, C.; Zhang, X.; An, L. A five-component entropy-stabilized fluorite oxide. J. Eur. Ceram. Soc. 2018, 38, 4161-4164. [CrossRef]

16. Dąbrowa, J.; Stygar, M.; Mikuła, A.; Knapik, A.; Mroczka, K.; Tejchman, W.; Danielewski, M.; Martin, M. Synthesis and microstructure of the $(\mathrm{Co}, \mathrm{Cr}, \mathrm{Fe}, \mathrm{Mn}, \mathrm{Ni})_{3} \mathrm{O}_{4}$ high entropy oxide characterized by spinel structure. Mater. Lett. 2018, 216, 32-36. [CrossRef]

17. Zaitseva, O.V.; Vinnik, D.A.; Trofimov, E.A. The Poly-Substituted M-Type Hexaferrite Crystals Growth. Mater. Sci. Forum 2019, 946, 186-191. [CrossRef]

18. Vinnik, D.; Zhivulin, V.; Trofimov, E.; Starikov, A.; Zherebtsov, D.; Zaitseva, O.; Gudkova, S.; Taskaev, S.; Klygach, D.; Vakhitov, M.; et al. Extremely Polysubstituted Magnetic Material Based on Magnetoplumbite with a Hexagonal Structure: Synthesis, Structure, Properties, Prospects. Nanomaterials 2019, 9, 559. [CrossRef]

19. Vinnik, D.A.; Trofimov, E.A.; Zhivulin, V.E.; Zaitseva, O.V.; Gudkova, S.A.; Starikov, A.Y.; Zherebtsov, D.A.; Kirsanova, A.A.; Häßner, M.; Niewa, R. High-entropy oxide phases with magnetoplumbite structure. Ceram. Int. 2019, 45, 12942-12948. [CrossRef]

20. Jiang, S.; Hu, T.; Gild, J.; Zhou, N.; Nie, J.; Qin, M.; Harrington, T.; Vecchio, K.; Luo, J. A new class of high-entropy perovskite oxides. Scr. Mater. 2018, 142, 116-120. [CrossRef]

21. Sarkar, A.; Djenadic, R.; Wang, D.; Hein, C.; Kautenburger, R.; Clemens, O.; Hahn, H. Rare earth and transition metal based entropy stabilised perovskite type oxides. J. Eur. Ceram. Soc. 2018, 38, 2318-2327. [CrossRef] 
22. Biesuz, M.; Fu, S.; Dong, J.; Jiang, A.; Ke, D.; Xu, Q.; Zhu, D.; Bortolotti, M.; Reece, M.J.; Hu, C.; et al. High entropy $\operatorname{Sr}\left(\left(\mathrm{Zr}_{0.94} \mathrm{Y}_{0.06}\right)_{0.2} \mathrm{Sn}_{0.2} \mathrm{Ti}_{0.2} \mathrm{Hf}_{0.2} \mathrm{Mn}_{0.2}\right) \mathrm{O}_{3-\mathrm{x}}$ perovskite synthesis by reactive spark plasma sintering. J. Asian Ceram. Soc. 2019, 7, 127-132. [CrossRef]

23. Sharma, Y.; Musico, B.L.; Gao, X.; Hua, C.; May, A.F.; Herklotz, A.; Rastogi, A.; Mandrus, D.; Yan, J.; Lee, H.N.; et al. Single-crystal high entropy perovskite oxide epitaxial films. Phys. Rev. Mater. 2018, 2, 60404. [CrossRef]

24. Zhong, Y.; Sabarou, H.; Yan, X.; Yang, M.; Gao, M.C.; Liu, X.; Sisson, R.D. Exploration of high entropy ceramics (HECs) with computational thermodynamics-A case study with $\mathrm{LaMnO}_{3 \pm \delta}$. Mater. Des. 2019, 182, 108060. [CrossRef]

(C) 2020 by the authors. Licensee MDPI, Basel, Switzerland. This article is an open access article distributed under the terms and conditions of the Creative Commons Attribution (CC BY) license (http://creativecommons.org/licenses/by/4.0/). 